To cite: RD Nanima 'Revisiting the normative framework of the African Commission on Human and Peoples' Rights in the context of evidence obtained through human rights violations: Has it served its purpose?' (2018) 18 African Human Rights Law Journal 1-26

http://dx.doi.org/10.17159/1996-2096/2018/v18n1a1

\title{
Revisiting the normative framework of the African Commission on Human and Peoples' Rights in the context of evidence obtained through human rights violations: Has it served its purpose?
}

\section{Robert D Nanima}

LLD Candidate; Co-ordinator, Graduate Lecturing Assistants' Programme, Faculty of Law, University of the Western Cape, South Africa

\begin{abstract}
Summary
This article examines the normative context of the African Commission on Human and Peoples' Rights in dealing with evidence obtained through human rights violations, and whether it serves its purpose. It unpacks the concept of a norm and uses the liberal school of thought as the theoretical framework, which informs the adoption of legal norms at the regional level. These, in turn, provide a yardstick that is used to evaluate the efficacy of the norms. With the aid of four normative developments between 1992 and 2003, it evaluates the extent to which these developments serve their purpose in dealing with evidence obtained through human rights violations. It is argued that while the Tunis Resolution and the Dakar Declaration have not served the purpose of dealing with evidence obtained through human rights violations, the Robben Island Guidelines specifically dealt with evidence obtained through torture. The adoption of the Principles can be reconciled with the African Commission's approach to the admission of evidence obtained through human rights violations.
\end{abstract}

Key words: African Commission; evidence; normative framework; violations

LLB (Makerere) LLM (Western Cape); rnanima@gmail.com. I am indebted to Prof Benyam Mezmur, Prof Isreal Leeman and the two anonymous reviewers for their insights on the initial draft. 


\section{Introduction}

The African Commission on Human and Peoples' Rights (African Commission) is the major institutional structure of the African human rights system. The African Charter on Human and Peoples' Rights (African Charter) $^{1}$ establishes the Commission with a mandate to promote and protect human rights. ${ }^{2}$ As an institutional structure, ${ }^{3}$ the African Commission uses existing norms to develop jurisprudence to guide it and state parties on human rights. ${ }^{4}$ The Commission may formulate and lay down principles and rules designed to solve legal problems arising out of human and peoples' rights and fundamental freedoms. ${ }^{5}$ It follows, therefore, that designing solutions that arise from legal issues emanating from evidence obtained through human rights violations is within the African Commission's mandate. This contribution questions the efficacy of the Commission's normative framework in dealing with evidence obtained through human rights violations. In a bid to contextualise a norm, the author uses a theoretical framework to understand the characteristics of a norm that led to its adoption. An evaluation of the sufficiency of this normative framework is undertaken and suggestions for reform follow.

Before an evaluation of the normative framework on the evidence obtained through human rights violations is made, it should be noted that a normative framework develops in two ways: first, through the intentional, deliberate development and its subsequent improvement by a human rights body. For instance, the African Commission's decision to improve the protection of the rights of women in Africa led to the adoption of the Protocol to the African Charter on Human and People's Rights on the Rights of Women in Africa (African Women's Protocol). ${ }^{6}$ Its normative framework was informed by the intention of the African Commission to formulate a law to protect the rights of women in Africa $^{7}$ and culminated into the adoption of the

1520 UNTS 217, art 30.

As above.

C Heyns 'The African regional human rights system: The African Charter' (200304) 108 Pennsylvania State Law Review 681.

4 T Buergenthal 'The normative and institutional evolution of international human rights' (1997) 19 Human Rights Quarterly 723.

5 Art 45(1)(b) African Charter; NJ Udombana 'The African Commission on Human and Peoples' Rights and the development of fair trial norms in Africa' (2006) 6 African Human Rights Law Journal 298305.

6 Protocol to the African Charter on Human and Peoples' Rights on the Rights of Women in Africa, adopted by the 2 nd ordinary session of the Assembly of the African Union, Maputo, CAB/LEG/66.6.

7 Seminar organised by the African Commission and Women in Law and Development in Africa (WILDAF) in Lomé, Togo in 1995, https://www.repro ductiverights.org/sites/crr.civicactions.net/files/documents/pub_bp_africa.pdf (accessed 20 April 2018). 
Lomé Resolution to prepare a protocol on the rights of women in Africa. ${ }^{8}$ This was followed by the adoption of the African Women's Protocol and, subsequently, General Comment 2 on articles 14(1)(a), (b), (c) and (f) and articles 14(2)(a) and (c) of the Women's Protocol.' Second, a normative framework may develop organically through the general improvement of other thematic concepts into a nuanced normative framework that deals with a specific aspect of human rights. This contribution adopts this second mode of development of a normative framework, and engages the thematic concept of evidence obtained through human rights violations.

The major normative developments with regard to evidence obtained through human rights violations include the Tunis Resolution on the Right to Recourse and a Fair Trial (Tunis Resolution); ${ }^{10}$ the Dakar Declaration on the Right to a Fair Trial in Africa (Dakar Declaration); ${ }^{11}$ and the Guidelines and Measures for the Prohibition and Prevention of Torture, Cruel, Inhuman or Degrading Treatment or Punishment in Africa (Robben Island Guidelines). ${ }^{12}$ The contribution also evaluates the Principles and Guidelines on the Right to a Fair Trial and Legal Assistance in Africa (Fair Trial Principles). ${ }^{13}$ The Guidelines on the Conditions of Arrest, Police Custody and PreTrial Detention in Africa 2014 (Luanda Guidelines) ${ }^{14}$ are not employed as they are still novel and have not yet been tested by the African Commission in the exercise of its mandate. The reasons that inform the adoption of these norms are offered in the course of their evaluation. It suffices to note that the normative developments were initiated by the inadequacy of article 7 of the African Charter with regard to the right to a fair trial. ${ }^{15}$ The study employs a desktop research-based review and analysis of the literature on normative frameworks. Case law and communications which offer jurisprudential developments are used to evaluate the effectiveness of the normative

8 Lomé Resolution AHG/Res.240 (XXXI) on the Recommendation of the African Commission on Human and Peoples' Rights to Prepare a Protocol on the Rights of Women in Africa.

9 General Comment 2 on arts 14(1)(a), (b), (c) and (f) and arts 14(2)(a) and (c) of the African Women's Protocol adopted by the African Commission at its 55th ordinary session held from 28 April to 12 May 2014 in Luanda, Angola.

10 Tunis Resolution on the Right to Recourse and Fair Trial (1992) Document ACHR/ Res.4 (XI) 92.

11 Dakar Declaration on the Right to a Fair Trial in Africa (1999) ACPHR/Res.41 (XXVI) 99.

12 Robben Island Guidelines; Resolution 61 (XXXII) 02 adopted by the African Commission at its 32nd ordinary session, 17-23 October 2002.

13 Principles and Guidelines on the Right to a Fair Trial and Legal Assistance in Africa, DOC/OS (XXX) 247; MA Baderin 'Recent developments in the African regional human rights system' (2005) 5 Human Rights Law Review 117-118.

14 Guidelines on the Conditions of Arrest, Police Custody and Pre-Trial Detention in Africa 2014 http://www.achpr.org/files/special-mechanisms/prisons-and-condi tions-of-detention/guidelines_arrest_police_custody_detention.pdf (accessed 7 March 2017).

15 F Ouguergouz The African Charter on Human and Peoples' Rights. A comprehensive agenda for human dignity and sustainable development in Africa (2009) 141. 
framework. With regard to the article, effectiveness means the ability of the normative framework as a source of soft law to deal with the admission of evidence obtained through human rights violations, from an interpretational perspective. The author submits that once the interpretation of the normative framework is appreciated, the application can be done in a manner that seeks to make the soft law relevant to the mandate of the African Commission.

\section{Conceptualising a normative framework}

Various meanings may be attached to a norm, which intertwines with the concept of a legal principle. The various definitions show that a norm and a legal principle are synonymous. A nuanced evaluation of the two concepts is instructive in aiding this contribution in establishing a norm. According to Jordan, a norm is synonymous with a legal principle or a standard upon which legal rules should be based. ${ }^{16}$ It is imperative to establish the standard that forms the basis of these aforementioned normative developments, who sets the standard, and where one looks to point to this standard. Therefore, African political, judicial and human rights issues need to be evaluated to ascertain the standard or basis of the norms. The normative structure, such as the Preamble and the content, is useful in discerning the standard of the norm. However, there is no drafting history of these developments, other than the writing up of the norms that have been formally adopted by state parties.

Jordan adds that a norm or a legal principle is a prevailing standard or set of standards of behaviour or judgment assumed to be just standards of behaviour for a society or for humanity in its entirety. ${ }^{17}$ This definition, first, points to the existence of different standards to a legal norm. However, it is not clear whether the different standards are evident in one particular norm, or exist across various norms. Second, the standards are assumed to be just. This is an indication that the justice of a given standard in a norm is an assumption which may be proved or disproved by its application over time. It is prudent to establish the norms that inform these assumptions. Third, the standards or set of standards are applicable to humanity as a whole. It should be recalled that the main challenge to the application of the norm lies in the commitment of a state party to ensure that it is used in the domestic jurisdiction.

On the other hand, Joaquin and Toube state that legal norms consist of legal rules and legal principles, which provide for standardised forms of behaviour for subjects of the law. ${ }^{18}$ This means that legal norms play a practical role of specifying or generalising

16 D Jordan 'Legal principles, legal values and legal norms: Are they the same or different' (2010) Academicus - International Scientific Journal 109.

17 As above.

18 JR-T Muñiz 'Legal principles and legal theory' (1997) 10 Ratio Juris 267. 
standards to be used to justify the validity of other written sources such as laws and subordinate legislation. ${ }^{19}$ The content that is specified or generalised by the norm forms a basis for the future development of the said norm. This description leads to pertinent questions, such as whether particular concepts are specified in a norm, the extent of their specification and what they seek to validate.

It follows from the above analysis that the concept of a norm entails its ability to handle a number of aspects: first, a standard or assumption that forms the basis of the norm; who sets the standard; and the content of the norm that points to this standard; second, the balancing of different standards in a norm or various norms, without conflating the spirit of the norm; third, the specification of a norm and the extent of its specification; and, fourth, the enforceability of the norm by human rights systems. The answers to these key points aid in the examination of the African Commission's mode of dealing with evidence obtained through human rights violations. Before using the four points to evaluate the norms, a review of the theoretical framework aids the understanding of a norm as a concept.

\section{Theoretical framework}

The international relations theory explains the emergence of norms in international human rights law. Various schools of thought inform this theory, such as constructivism; Marxism; idealism; realism; and liberalism. ${ }^{20}$ Before evaluating the theory, the historical background to the theory will aid in the appreciation of its contemporary nature.

The liberal theory has among its origins the works of Immanuel Kant (1724-1804), who agitated for a peace programme to be followed by states. ${ }^{21}$ Kant was of the view that the success of the programme would rely on mutual co-operation between states as they pursued freedoms and benefits. ${ }^{22}$ He offered four principles which over time have aided in the development of the liberal theory. First, he believed that the actions of the state at the international level were a product of a focus on a domestic process. It meant that there are various players on the domestic scene, who influence the state's decisions in signing treaties and adopting laws, and pointed to the need to disaggregate the state from a unitary system to an allinclusive system which ensured that domestic players performed a key role in state actions. ${ }^{23}$

19 Jordan (n 16 above) 113.

20 This is not a closed list of schools of thought that inform the international relations theory. Other theories may include international political economy; feminism; functionalism; post-modernism; post-colonialism; and hegemonic stability theory.

21 I Kant 'Perpetual peace: A philosophical sketch' (1795) https://www.mtholyoke. edu/acad/intrel/kant/kant1.htm (accessed 30 June 2018).

22 Kant (n 21 above) sec I.

23 OA Hathaway 'Do human rights treaties make a difference?' (2002) 111 Yale Law Journal 1935 at 1952. 
Kant's works were premised on the need for a democratic process. He stated that '[t]he civil constitution of every state shall be republican'.24

Kant's concept of 'republican' was understood to mean a constitution established by a democratic process, which upheld principles of freedom, the rule of law and equality. ${ }^{25}$ This concept has been applied in the contemporary era as the state's engagement with its citizens in the running of its affairs with the purpose of achieving peace. $^{26}$ The state has to account to its citizens as the domestic players with regard to its actions on the international scene. This position recognises the constitution as the grand norm in a domestic jurisdiction, which empowers its citizens to guide the state's actions. States, therefore, cannot be labelled as unitary entities that decide what they want contrary to the needs of their citizens. Rather, decisions of the state as a democratic entity are influenced by domestic players such as political groups, interest groups, nongovernmental organisations (NGOs) and civil society. ${ }^{27}$

In the second place, Kant formed the opinion that the 'law of the nations shall be founded on a federation of free states'. ${ }^{28}$ This proposition meant for states to have a uniform law that applies in their various territories; they ought to have that uniform system of government in the domestic territory, for example, democracy. This uniformity would ensure that they benefit from the use of normative principles that spoke to the nature of governments at home. It follows that states that did not comply with this requirement were not eligible to be members of or to be bound by this law of nations. Citing other thinkers, such as Hugo and Grotius, who justified the existence of war, Kant believed that war led to lawlessness that could not be attributed to the law of states. Some writers were of the opinion that this may mean war by states. However, it refers to tensions within states that arise out of the failure to have meaningful engagement on issues that affect a state in the domestic sphere. ${ }^{29}$

Third, he stated that ' $[\mathrm{t}]$ he law of world citizenry shall be limited to the condition of universal hospitality'. ${ }^{30}$ According to Kant, the freedoms that an individual enjoyed in his domestic jurisdiction had to be enjoyed in all domestic jurisdictions. With regard to the first principle, the effect of this principle is that the role of the domestic players in guiding states to action on the international scene had to be uniform in all jurisdictions. This uniformity was recognised in the adoption of the rules at the international level by states. This principle

24 Kant (n 21 above) sec II, first definitive article for a perpetual peace.

25 As above.

26 Hathaway (n 23 above) 1952.

27 As above.

28 Kant (n 21 above) sec II, second definitive article for a perpetual peace.

29 Hathaway (n 23 above) 1953.

30 Kant (n 21 above) sec II, third definitive article for a perpetual peace. See Hathaway (n 23 above) 1952. 
recognised the universality of the rights of an individual, such as the right to a fair trial, equality, and freedom and security of the person. ${ }^{31}$

\subsection{Liberal school of thought}

This article limits its scope to the liberal school of thought in the international relations theory (liberal theory), to explain the creation of norms on the regional plane. This theory provides: ${ }^{32}$

The relationship between states and the surrounding domestic and transnational society in which they are embedded critically shapes state behaviour by influencing the social purposes underlying state preferences [and] can be restated in terms of three core assumptions. These assumptions are appropriate foundations of any social theory of international relations: They specify the nature of societal actors, the state, and the international system.

The theory assumes that there has to be a relationship between the state and its actors who usually are the government in power. On the other hand, there are the domestic players, such as civil society, NGOs and political or socio-economic groups. These players direct the decisions of the state at the international level through their provision of shadow reports to international organisations. ${ }^{33}$ They may oppose the position of the state by enforcing their own position in that they have a stake in the leadership of a country. This relationship leads to the creation of a purpose in a domestic jurisdiction which provokes a conflict between the state and domestic players. This conflict leads to the need for co-operation on the course of action. This course of action informs the action or the foreign policy of the state at an international or regional level.

The theory is informed by three principles: first, that power politics is not the only outcome that may arise from international relations. ${ }^{34}$ Other outcomes may be decisions influenced by the domestic players. Second, these decisions are mutual benefits, which arise out of international co-operation. This co-operation arises out of the conflict that arises in the domestic sphere and informs the need for cooperation between the state and the domestic players. Third, the domestic players shape state action and policy at the international level. ${ }^{35}$ These three principles indicate a departure from other schools of thought in various respects. According to the realists, the central actors in international politics are the state actors other than the individuals or domestic players. Second, this political system at the

31 These rights are now provided for in international and regional human rights instruments.

32 A Moravcsik 'Taking preferences seriously: A liberal theory of international politics' (1997) 51 International Organisation 513516.

$33 \mathrm{Eg}$, there is a shadow report to the African Commission by Amnesty International on Eritrea, https://www.amnesty.org/en/documents/afr64/8161/2018/en/ (accessed 21 April 2018).

34 EB Shiraev \& VM Zubok International relations (2015) 78.

35 As above. 
international level implies anarchy with no recourse to a supranational authority to enforce rules. Third, the state actors as the central players are rational in so far as their actions maximise their self-interest. Fourth, the existence of power held by state parties serves their selfpreservation and not the interests of the societal players. ${ }^{36}$ The creation of any norms, therefore, is based on what the state party wants with no regard to the interests of domestic players.

Constructivism, on the other hand, states that the structures of human association arise out of shared ideas other than material forces, whether as domestic players or state actors. ${ }^{37}$ This school of thought further states that the characteristics and interests of both parties arise from shared ideas instead of the respective contemporary positions of the domestic players. ${ }^{38}$ The outcome, therefore, of an international engagement by the states is as a result of constructive and equal engagement with various stakeholders. Norms should be created through the concerted effort of both the domestic players and the state. This school of thought disregards the fact that there are always unequal players in both the domestic arena and the state.

Another school of thought is idealism, which provides that a state should have a philosophy that guides its foreign policy and the subsequent actions it takes as a way of providing transformation in the domestic sphere. ${ }^{39}$ A perfect example is the policy of the United States of America to negotiate the contents of international treaties, yet taking a long time to sign, accede or ratify them. ${ }^{40}$ The structure of the international relations of a state should be able to transform it into the desired state of being. This line of thought, however, does not consider the biases, the various shortcomings, and the negative motives that may inform its philosophy in the creation of norms. Therefore, with regard to the creation of norms using the liberal theory, one needs to evaluate the formation of norms at the international level as a result of domestic players who prevail on the state to take action.

\subsection{Tenets of the liberal theory}

The liberal theory relates to a distinct ideology that is created by the domestic players who shape the perceptions, capacities and actions of the state in the political, social and economic areas of a particular state. ${ }^{41}$ It may be interpreted as an ideology propagated by domestic

36 RE Goodin 'The state of the discipline, the discipline and the state' in RE Goodin (ed) The Oxford handbook of political science (2011) 8.

37 A Wendt Social theory of international politics (1999) 1.

38 As above.

39 D Markwell John Maynard Keynes and international relations: Economic paths to war and peace (2006) 3.

40 CA Bradley 'Unratified treaties, domestic politics, and the US Constitution' (2007) 48 Harvard International Law Journal 307.

41 DW Michael 'Kant, liberal legacies, and foreign affairs' (1983) 12 Philosophy and Public Affairs 206. 
players intended to influence decisions or actions or policies of a state at an international level. Therefore, what affects the common man forms the agenda for redress at the international level. As a result, the theory enhances the freedoms of an individual. ${ }^{42}$ The theory assumes that people and states seek welfare, and use reason instructively to design strategies and institutions that are conducive to attaining this goal. ${ }^{43}$ If a norm does not improve the welfare of the people within its jurisdiction, then a state should not adopt it.

The first tenet provides: ${ }^{44}$

The fundamental actors in international politics are individuals and private groups, who are on the average rational and risk-averse and who organise exchange and collective action to promote differentiated interests under constraints imposed by material scarcity, conflicting values, and variations in societal influence.

The main actors on the international political scene are individuals or private organisations. ${ }^{45}$ These engage collectively to promote various interests of the people within the jurisdiction of a given state party. ${ }^{46}$ Existing limitations, such as different values and differences in the ability to guide decisions, may affect their effectiveness. ${ }^{47}$ The use of a bottom-up approach is designed to enhance independence from political influence. It advances interests for the common good of the people within the state's jurisdiction. The structures in a domestic framework, therefore, mould state behaviour towards a common quality of outcomes. ${ }^{48}$

The second tenet provides: ${ }^{49}$

States (or other political institutions) represent some subset of domestic society, on the basis of whose interests state offıcials define state preferences and act purposively in world politics.

This provision means that the state through its actions represents the concerns of the domestic players other than its concerns as a unitary body. The state acts as the tool that is used to achieve the goals, which may not otherwise be achieved by individuals at the international level. A state adopts a declaration or a resolution for the good of its people other than its self-preservation. Self-preservation is contextualised as the urge by a government to cling to power through the abuse of human rights violations, and the quelling of any

42 As above.

43 RN Lebow A cultural theory of international relations (2008) 74.

44 Moravcsik (n 32 above) 517.

45 S Haggard \& BA Simmons 'Theories of international regimes' (1987) 41 International Organisations 491499.

46 As above.

47 As above.

48 As above.

49 Moravcsik (n 32 above) 518. 
form of resistance. ${ }^{50}$ It follows that clinging on to power as a mode of self- preservation against the will of the masses is not for the 'good of the people'. 51 This tenet, however, assumes that all individuals have equal influence on state policy. The domestic players may be composed of obscure groups that do not influence decisions like other domestic players or state actors. For instance, a small political party or civil society organisation may not have the force to direct state policy as do established political parties or civil society organisations. It may pass as a narrow pluralist perception of domestic politics, where all individuals and groups have equal influence on state policy, but is not always the case. More often than not the state does not represent the views of its people equally.

The third tenet provides that '[t]he configuration of interdependent state preferences determines state behaviour' ${ }^{52}$ The behaviour or the actions of the state are a reflection of the various patterns of state preferences. These actions are guided by a purpose that provokes conflict, proposes co-operation, and culminates in the adoption of foreign policy action, which benefits the people within its jurisdiction. ${ }^{53}$ It may be said that when a state party assents to or ratifies or signs a treaty, its action is informed by the position of the domestic players. Thus, the variation in the means used leads to an expected end. The fallacy with this approach is that it may be taken to be a reductionist one, rather than a systemic understanding between the domestic players and the state. ${ }^{54}$

This theory is evident in various passages of the African Charter. The Charter provides that '[e]very individual shall have duties towards his family and society, the state and other legally recognised communities and the international community'. ${ }^{53}$ This provision recognises that an individual plays a distinct role in the affairs of his or her family and at a subtle level in the community. The duties to the community inform the affairs of the state or other communities at the level of the state, such as kingdoms, and cultural institutions. The apex of the performance of these duties is seen in the actions of the state at the international level. This contribution, therefore, validates the application of the liberal theory to the African Charter. In addition,

50 For more on the state's use of self-preservation, see AL Fuller Taking the fight to the enemy: Neo-conservatism and the age of ideology (2011) 230. Compare with Morgenthau's model in F Rösch Power, knowledge, and dissent in Morgenthau's worldview (2016) generally.

51 A detailed engagement with self-preservation and the good of the people is beyond the scope of this article. One may consider the recent events in Zimbabwe that illustrate that a change in the leadership of the country, despite its constitutional ramifications, to a great extent was geared towards the good of the people and an act of putting a stop to self-preservation by Robert Mugabe's government.

52 Moravcsik (n 32 above) 518.

53 Moravcsik 520.

54 Moravcsik 522.

55 Art 27(1) African Charter. 
the individual has the duty to 'preserve and strengthen social and national solidarity, particularly when the latter is threatened'. ${ }^{56}$ This provision mandates the individual to ensure that the state does not threaten individual freedoms and a collective duty to agitate for state action to improve welfare.

The African Commission is mandated as follows with regard to the exercise of its functions: 57

To promote human and peoples' rights and in particular ... to collect documents, undertake studies and researches on African problems in the field of human and peoples' rights, organise seminars, symposia, and conferences, disseminate information, encourage national and local institutions concerned with human and peoples' rights, and should the case arise, give its views or make recommendations to governments.

The provision points to the critical role that national and local institutions play in the forging of decisions by the African Commission. The views of these domestic players form the Commission's recommendations to state parties. ${ }^{58}$ This provision points to the critical role of domestic players in forming the foreign policy of their respective state parties at the international level. This line of thought also forms the basis of the inclusion of the views of civil society when monitoring a state party's adherence to the African Charter.

\section{Use of normative developments between 1992 and 2003}

The right to a fair trial includes the question of evidence obtained through human rights violations. This evidence, the admissibility of which may be questioned in the course of a trial, may affect the fairness of a trial. The literature indicates that most normative developments on the right to a fair trial occurred between 1992 and 2003. This study scrutinises this period to establish which normative developments point to the right to a fair trial, with an emphasis on the mode of dealing with evidence obtained through human rights violations. The evaluation of these developments offers insights into whether the normative developments have dealt with evidence obtained through human rights violations, and to what extent these developments deal with this impugned evidence.

According to Odinkalu, the African Union's normative developments on the right to a fair trial commenced in 2002.59 Odinkalu gives no justification for a retrospective review of the period

56 Art 29(4) African Charter.

57 Art 45(1)(a) African Charter.

58 Moravcsik (n 32 above) 518-522.

59 CA Odinkalu 'Human rights mechanisms in Africa: Recent developments in their norms, institutions and jurisprudence' (2003) 3 Human Rights Law Review 105. 
before 2002 and there has been no corresponding update to his earlier study. Banderin makes use of jurisprudential developments by the African Commission to gauge the normative frameworks as a basis. His insights are instructive as far as they implicitly show how the Commission has interpreted its normative framework in developing its jurisprudence in the communications brought before it. He analyses three communications to show that normative frameworks underscore the developments. The decisions in Law Office of Ghazi Suleiman $v$ Sudan (II), ${ }^{60}$ Doebbler $v$ Sudan ${ }^{61}$ and Purohit \& Another v The Gambia ${ }^{62}$ deal respectively with the right to freedom of expression and democracy in Africa; Islamic law and human rights in Africa; and the human rights of mental health patients in Africa. However, they fail to offer any insight into norms that determine evidence obtained through human rights violations. This failure validates this research by indicating that one has to appreciate the history and scope of a normative framework before applying it in the development of jurisprudence. The researcher, therefore, is justified in evaluating the norms that may be instructive to understanding the African Commission's principles on evidence obtained through human rights violations.

According to Ouguergouz, the African Commission was aware of the fact that article 7 of the African Charter did not adequately deal with the right to a fair trial. ${ }^{63}$ This led to the adoption of a series of soft law measures that could resolve this lacuna, ${ }^{64}$ such as resolutions, $^{65}$ declarations, ${ }^{66}$ legal principles ${ }^{67}$ and guidelines. ${ }^{68}$ Other authors suggest that some of the soft law adopted by the African Commission in 2002 has not been valuable in dealing with human rights violations such as torture. ${ }^{69}$ This failure points to a limitation in developing jurisprudence by the Commission. Equally it points to a poor standard or assumption that a given law seeks to accomplish, and illustrates the need to revisit each norm to establish the standard or assumption it stands for and how it contributes to the normative framework of evidence obtained through human rights violations.

60 (2003) AHRLR 144 (ACHPR 2003).

61 (2003) AHRLR 153 (ACHPR 2003).

62 (2003) AHRLR 96 (ACHPR 2003).

63 Ouguergouz (n 15 above) 141.

64 The relevant norms that form this soft law will be dealt with shortly.

65 Tunis Resolution (n 10 above).

66 Dakar Declaration (n 11 above).

67 The Principles (n 13 above).

68 Dakar Declaration (n 11 above) para 3.

69 D Long \& R Murray 'Ten years of the Robben Island Guidelines and Prevention of Torture in Africa: For what purpose?' (2012) 12 African Human Rights Law Journal 311. 
Mujuzi's analysis of the African Commission's communication of the Egyptian Initiative for Personal Rights and Interights $v$ Arab Republic of Egypt $^{70}$ is a point of departure from the foregoing literature. His engagement with the decision shows that there has been a progressive development of the Commission's normative framework with regard to evidence obtained through human rights violations. Three milestones are evident from his analysis to show the progressive development. First, the Tunis Declaration and the Dakar Declaration deal with the improvement of the right to a fair trial from a general continuum. Second, the Robben Island Guidelines deal with specific aspects such as the non-admission of evidence obtained though torture. Third, the Principles engage the admission of evidence obtained through human rights violations. While his review shows a development with regard to dealing with evidence obtained through torture, the latter forms a small and the most egregious part of the rights that can be susceptible to evidence obtained through human rights violations. The researcher questions the answers that the Principles offer with regard to its normative structure in dealing with evidence obtained through human rights violations. Second, the Principles show a positive normative framework that deals with evidence obtained through human rights violations. The study notes the lessons that are instructive for future normative developments.

On the basis of the foregoing literature, the study narrows its focus to four major normative developments that relate to the right to a fair trial, with the emphasis on evidence obtained through human rights violations. These include the Tunis Resolution; ${ }^{71}$ the Dakar Declaration; ${ }^{72}$ the Robben Island Guidelines; ${ }^{73}$ and the Fair Trial Principles. ${ }^{74}$ The most recent normative development with regard to evidence obtained through human rights violations is the Guidelines on the Conditions of Arrest, Police Custody and Pre-Trial Detention in Africa adopted in 2014 (Luanda Guidelines). ${ }^{75}$ The researcher is of the opinion that it is premature to evaluate whether these guidelines have served their purpose. A conscious decision has been made to exclude these Guidelines from the study. However, it should be stated in the interim that the Luanda Guidelines address some issues that are not dealt with by the Tunis Resolution, the Dakar Declaration, the Robben Island Guidelines and the Fair Trial Principles. First, the Luanda Guidelines require that any evidence obtained in violation of confidentiality of information between legal counsel and the suspect is inadmissible. ${ }^{76}$ Second, the Luanda Guidelines emphasise that an

70 JD Mujuzi 'The African Commission on Human and Peoples' Rights and the admissibility of evidence obtained as a result of torture, cruel, inhuman and degrading treatment: Egyptian initiative for Personal Rights and Interights $v$ Arab Republic of Egypt' (2013) 17 International Journal of Evidence and Proof 287.

71 Tunis Resolution (n 10 above).

72 As above.

73 Robben Island Guidelines (n 12 above).

74 Luanda Guidelines (n 14 above). Banderin (n 13 above) 117-118.

75 Luanda Guidelines (n 14 above). 
accused is informed of the right to the presence and assistance of a lawyer or suitably-qualified paralegal before a confession is recorded. ${ }^{77}$ This requirement extends to the accused's enjoyment of this right in the course of recording the confession. ${ }^{78}$

\subsection{Tunis Resolution on the Right to a Fair Trial}

The Tunis Resolution was adopted by the African Commission at its 11 th ordinary session in Tunis. The Commission reiterated its mandate to promote and protect human rights according to the African Charter and international standards. ${ }^{79}$ In addition, the Tunis Resolution recognised the importance of the right to a fair trial under article 7 of the African Charter, in ensuring the right to a fair trial. ${ }^{80}$ Therefore, the requirement to uphold the right to a fair trial in international and regional law was the standard that informed the adoption of the Resolution by state parties. This standard, however, did not address the specific aspects relating to evidence obtained through human rights violations. The Resolution assumed the provision of the right to a fair trial to be a just cause, which had to be upheld by state parties. ${ }^{81}$ This assumption, however, did not convey justice in so far as the Resolution did not deal with evidence obtained through human rights violations.

The Resolution was specifically addressed to state parties to inform persons in their jurisdiction of the remedies and the procedure relevant thereto. ${ }^{82} \mathrm{~A}$ remedy with regard to the admission of impugned evidence featured nowhere in the Resolution. The Resolution required state parties to provide needy persons with legal aid. ${ }^{83}$ The provision of legal aid did not necessarily lead to the exclusion of evidence obtained through human rights violations. The Resolution lacked guidance as to the extent of the available remedies, especially with regard to evidence obtained through human rights violations, such as the non-admission of this evidence, or the procedure to be followed in dealing with such evidence. This failure indicated that the standard and assumption that formed the basis of the norm was not sufficient to ensure the right to a fair trial in instances where there was evidence obtained through human rights violations. The failure to address evidence obtained through human rights violations impeded the ability of the Resolution to influence the mode of dealing with evidence obtained through human rights violations. However, its attempt at improving the standards of the

76 Art 8(d)(ii) Luanda Guidelines.

77 Art 9(a)(i) Luanda Guidelines.

78 Art 9(a)(ii) Luanda Guidelines. Compare with Principle $N(6)(d)(1)$ and (2) of the Principles.

79 Para 1 Tunis Resolution (n 10 above).

80 Paras 2-5 Tunis Resolution.

81 Paras $3 \& 6$ Tunis Resolution.

82 Paras 2-5 Tunis Resolution.

83 As above. 
right to a fair trial indicated that it recognised individuals and their wellbeing as a paramount consideration. ${ }^{84}$ However, it failed to deal with instances that spoke to the specific tendencies by state parties that led to the admission of evidence obtained through human rights violations. It is on this basis that one may conclude that the Tunis Resolution did not deal with the specific aspects of the right to a fair trial, such as evidence obtained through human rights violations. The Tunis Resolution as part of the normative framework was effective in improving the right to a fair trial generally. However, this effectiveness does not speak to evidence obtained though human rights violations in so far as it did not address instances of evidence obtained through human rights violations.

\subsection{Dakar Declaration}

Another development occurred in September 1999 culminating in the adoption of the Dakar Declaration. ${ }^{85}$ This Declaration, which was a product of engagements with civil society organisations, academics and lawyers, targeted state parties. As in the case of the Tunis Resolution, the right to a fair trial was the normative standard. With regard to the balancing or extent of the standard of this norm the African Commission formed the opinion that the realisation of this right depended on four aspects. The first aspect was the elimination of certain practices by state parties. ${ }^{86}$ These practices included state parties' use of acts of impunity such as the torture of suspects in pretrial detention. This aspect was informed by the political, social and economic circumstances that affected the realisation of fair trials in Africa, such as armed conflicts, massive human rights violations and the lack of tangible methods to implement the obligations assumed under treaties. $^{87}$

In the second place, the Declaration emphasised the need for state parties to respect the rule of law. ${ }^{88}$ This indication was instrumental in ensuring that respect for the right to a fair trial was in an enabling environment where the rule of law subsisted. ${ }^{89}$ The insistence by the Declaration on the need for accountability by political institutions offered insights into the fact that evidence obtained through human rights violations would be challenged in courts of law. The rule of law required the existence of fully-accountable political institutions where

84 Moravcsik (n 44 above) 517 on the primacy of the domestic society that represents the interests of individuals in a domestic jurisdiction.

85 Dakar Declaration (n 11 above).

86 Paras 3 \& 6 Dakar Declaration.

87 Para 4 Dakar Declaration.

88 Para 7 Dakar Declaration.

89 As above. 
state parties, through their agents, did not acquire evidence obtained through human rights violations. 90

Third, the African Commission advocated the independence and impartiality of the judiciary. ${ }^{91}$ This independence related to the appointment, security and tenure of the members of the judiciary, while the impartiality related to the ability of the judiciary to hand down decisions without the influence of any organ or person. ${ }^{92}$ This issue ought to be distinguished from the first point above. The first point dealt with instances before the hearing of a case, where state parties engaged in acts that compromised a fair trial of a suspect, such as torture. With regard to the current point, it related to the need to guard the tenure of judicial officers to ensure that they exercised independence in handing down decisions. The African Commission's advocacy of the system of appointment, tenure and removal of judges, however, did not deal with a scenario where a state party would have a vibrant legal regime governing the judiciary, while it lacked rules to govern evidence that had been obtained through human rights violations. ${ }^{93}$ As a result of this standard, the requirement to deal with evidence obtained through human rights violations was not directly dealt with, because the concept dealt with the offices of the judiciary other than issues dealing with the admission of evidence. To a small extent respect for the rule of law provided insights into the possibility of dealing with evidence obtained through human rights violations.

In the fourth place, the African Commission recognised that most state parties had military courts and special tribunals that operated alongside the institutionalised courts of judicature. ${ }^{94}$ It insisted that although the military courts adjudicated offences of a military nature, they had to adhere to fair trial standards. ${ }^{95}$ The special tribunals were not expected to try offences that would be tried by the institutionalised courts of judicature. ${ }^{96}$

The African Commission did not pronounce itself on whether these military courts had to use the same rules of evidence that were used in

90 This was largely limited to instances of torture, cruel, inhumane and degrading treatment, which was a small aspect of evidence that would be obtained through human rights violations.

91 Para 8 Dakar Declaration (n 11 above).

92 As above.

93 The Constitution of the Republic of Uganda, 1995 provided for a robust system in arts 126-151 on the judiciary. It still lacks a law on evidence obtained through human rights violations (RD Nanima 'The legal status of evidence obtained through human rights violations in Uganda' (2016) 19 Potchefstroom Electronic Law Journal 1-38 generally). The same was evident in the Constitution of the Republic of Kenya, 1963, which had a legal regime concerning the judiciary, but lacked a provision on evidence obtained through human rights violations. The same was evident in the 1980 Lancaster Constitution of Zimbabwe.

94 Para 9 Dakar Declaration (n 11 above).

95 As above.

96 As above. 
the institutionalised courts in adducing evidence. This omission affected the enforceability of the fair trial standards that the Declaration alluded to. This insight would have led to the realisation of the fact that a rule on the admissibility of evidence obtained through human rights violations would affect the trial process in all these courts. In Uganda, for instance, the court martial adjudicates offences that are similar to the offences in the Penal Code Act. The question of which rules of evidence are used is not clear. ${ }^{97}$ The African Commission's normative stand on evidence obtained through human rights violations remained an issue of implication rather than clarity. ${ }^{98}$

The African Commission recognised that the bar associations, as domestic players, were essential to the enhancement of the right to a fair trial. ${ }^{99}$ The ability of lawyers to represent clients without intimidation or harassment from other organs or persons was the bedrock of the right to a fair trial. ${ }^{100}$ Even though this position is disregarded by the realist school of thought, which that looks at the state as a unitary body that seeks to maintain its self-preservation, 101 it could be true to a given extent that bar associations played an oversight role which might be ignored by state parties. In Law Office of Ghazi $v$ Sudan (I), the complainant was arrested and incarcerated as he represented persons who were critical of the government. ${ }^{102}$ This incident shows that the actions of the state point to its use of anarchy, and focus on the need for self-preservation. ${ }^{103}$ In a liberal view the lodging of complaints with the African Commission is indicative of the consequence of a state that tries to suffocate the views of its domestic players. ${ }^{104}$ The researcher insists that the issues dealing with evidence obtained through human rights violations should take centre stage. The bar associations would then act as a buffer, which would ensure that evidence obtained through human rights violations would not be admitted.

The African Commission recognised the lack of effective remedies by state parties in dealing with the right to a fair trial. ${ }^{105}$ This recognition was a reiteration of the Commission's use of a general perspective in the emphasis on the general improvement of the right

97 The Uganda People's Defence Act, 2005, which establishes the court martial, by implication uses the same rules of evidence that govern criminal law and procedure. See sec 217 of the Uganda People's Defence Act.

98 The same was evident in the African Commission's declaration in para 10 with regard to traditional courts. While it appreciated the courts' role in promoting social cohesion, the Commission failed to hint at the mode of admission of evidence.

99 Para 11 Dakar Declaration (n 11 above). Moravcsik (n 28 above) 517.

100 Para 11 Dakar Declaration.

101 Goodin (n 36 above) 133.

102 (2003) AHRLR 134 (ACHPR 2003).

103 Goodin (n 36 above) 133. See the detailed discussion on the theoretical framework above.

104 Hathaway (n 23 above) 1953.

105 Para 6. See paras 1-4 of the Tunis Resolution (n 6 above). 
to a fair trial. This position is proved through its reference to punitive, restorative and compensatory remedies. ${ }^{106}$ The failure to take a stand on evidence obtained through human rights violations affected the enforcement of a rule to that effect. It would have been better if the remedies with regard to punishment included the exclusion of evidence obtained through human rights violations and the use of such evidence against the perpetrators of human rights violations. The African Commission's desire was to have fair trial standards, whereby state parties provided adequate protection of victims' rights and interests. ${ }^{107}$ This position, however, required clarity on some procedural aspects of admitting evidence, such as subjecting the evidence to a trial within a trial to ascertain its voluntariness. Although the accused persons were to receive legal aid, the failure to question the voluntariness of evidence obtained through human rights violations meant that the accused still would suffer from the probable use of evidence obtained in abuse of their rights.

The Dakar Declaration did not deal directly with issues concerning evidence obtained through human rights violations. As in the case of the Tunis Resolution, it referred to the general component of the right to a fair trial in terms of legal representation and independence of the judiciary in the appointment, tenure and removal of judicial officers. Aspects dealing with evidence obtained through human rights violations were not dealt with. In the author's opinion the circumstances on the continent maintained the focus of the African Commission on the general right to a fair trial. As a result this normative development was inclined to those principles that affected the right to a fair trial. This position presents the lack of oversight by the Commission with regard to questions that would arise in dealing with evidence obtained through human rights violations. However, the recognition by the Declaration of the four key aspects that affected an individual and the domestic institutions, such as the judiciary and the bar associations, showed that their legal protection was key to their contribution to the formation of the foreign policy of a state party. ${ }^{108}$ It is evident that the concepts engaged under the Dakar Declaration served the purpose of illustrating that acts of impunity by state parties had to end, and that the independence of the judiciary had to be protected. This effectiveness did not extend to dealing with instances of evidence obtained though human rights violations.

\subsection{Robben Island Guidelines}

The Robben Island Guidelines were adopted by the African Commission against the backdrop that there was a need to

106 Para 13 Dakar Declaration.

107 As above.

108 Moravcsik (n 44 above) 518, on the role of domestic players on formation of a state's foreign policy. 
implement the various international and regional instruments with regard to torture and cruel, inhuman and degrading treatment. The requirement to deal with torture and cruel, inhuman and degrading treatment informs the normative standard for the Robben Island Guidelines.

The Preamble recalls 'the universal condemnation and prohibition of torture, cruel, inhuman and degrading treatment and punishment $^{\prime 109}$ and recognises 'the need to take positive steps to further the implementation of the existing provisions on the prohibition of torture, cruel, inhuman and degrading treatment and punishment ${ }^{\prime}{ }^{110}$ It is discernible from the Preamble that the Robben Island Guidelines radically depart from the preceding legal norms that used the right to a fair trial as the standard for implementation of the right by embracing a mode of dealing with evidence obtained through human rights violations. With the aid of the universal condemnation and prohibition of torture as the standard, the Robben Island Guidelines employ a tight standard, which relates to the prohibition of torture, other than the general enforcement of the right to a fair trial. ${ }^{111}$ However, this standard is inclined towards the right against torture and cruel, inhuman and degrading treatment to the exclusion of all other rights which would be abused in the cause of adducing evidence. Even if the standard created a focus on evidence obtained through human rights violations, it included only the right against torture. This focus meant that a person whose right to the presumption of innocence had been violated could not claim a violation of his rights under the Robben Island Guidelines unless the violation was related to torture. ${ }^{112}$

The generalisations in the Robben Island Guidelines relating to torture and cruel, inhuman and degrading treatment and punishment are addressed to state parties. The states are required to

(e)nsure that any statement obtained through the use of torture, cruel, inhuman or degrading treatment or punishment shall not be admissible as evidence in any proceedings except against persons accused of torture as evidence that the statement was made.

As such, the Robben Island Guidelines are limited to the nonadmission of evidence obtained through torture and cruel, inhuman and degrading treatment, to the exclusion of evidence obtained through other human rights violations. It is not in doubt that there are

109 Preamble para 1 Robben Island Guidelines (n 12 above).

110 Para 4 Robben Island Guidelines.

111 Para 7 Robben Island Guidelines.

112 Art 1 of the United Nations Convention Against Torture and Other Cruel, Inhuman or Degrading Treatment or Punishment (1984), adopted by General Assembly Resolution 39/46 on 10 December 1984, entered into force on 26 June 1987 ; art 5 of the Universal Declaration of Human Rights (1948); art 5 of the African Charter; Communication 416/12 Jean-Marie Atangana Mebara $v$ Cameroon, paras 81-83.

113 Robben Island Guidelines (n 12 above) Guideline 29. 
international human rights instruments that deal with torture. ${ }^{114}$ To a great extent these instruments form a basis for the Robben Island Guidelines. 115 One may argue that the Robben Island Guidelines reflect the content of international instruments, but its effectiveness ought to be seen in its application as a normative instrument. ${ }^{116}$ It is on this basis that one may conclude that these guidelines do not provide useful direction in interpreting article 5 of the African Charter. ${ }^{117}$ As such, there is a need for them to provide a structure to use in dealing with torture.

Pursuant to the implementation of the regional and international instruments on torture, the Guidelines require 'ratification of the Protocol to the African Charter on Human and Peoples' Rights Establishing an African Court on Human and Peoples' Rights'. ${ }^{118}$ This Protocol established the African Court with a mandate to complement the African Commission in the promotion and protection of human rights in Africa. ${ }^{119}$ One may argue that it does not provide clarity on the admission of evidence obtained through human rights violations. This position is countered as far the Protocol provides that '[i]f the Court finds that there has been a violation of a human or peoples' right, it shall make appropriate orders to remedy the violation, including the payment of fair compensation or reparation'.120 'In cases of extreme gravity and urgency, and when necessary to avoid

114 UN Convention Against Torture, Cruel, Inhuman and Degrading Treatment 1465 UNTS 85 .

115 Art 6 of the Universal Declaration, adopted by General Assembly Resolution 217 A(III) of 10 December 1948; Standard Minimum Rules for the Treatment of Prisoners (1955), adopted by the First United Nations Congress on the Prevention of Crime and the Treatment of Offenders, held at Geneva on 30 August 1955, and approved by the Economic and Social Council by its Resolutions 663 C (XXIV) of 31 July 1957 and 2076 (LXII) of 13 May 1977; art 8 of the International Covenant on Civil and Political Rights (1966) 999 UNTS 171; Declaration on the Protection of All Persons from Being Subjected to Torture and Other Cruel, Inhuman or Degrading Treatment or Punishment $(1975)$ adopted by General Assembly Resolution 3452 (XXX) of 9 December 1975; arts 2 and 5 of the Code of Conduct for Law Enforcement Officials, adopted by General Assembly Resolution 34/169 of 17 December 1979; United Nations Convention against Torture and Other Cruel, Inhuman or Degrading Treatment or Punishment (1984) 1465 UNTS 85; art 1 of the Body of Principles for the Protection of All Persons under Any Form of Detention or Imprisonment (1988) adopted by General Assembly Resolution 43/ 173 of 9 December 1988; art 5 of the African Charter.

116 Long \& Murray (n 69 above) 311.

117 As above.

118 Robben Island Guidelines (n 12 above) Guideline 1(a).

119 Protocol to the African Charter on Human and Peoples' Rights on the Establishment of an African Court on Human and Peoples' Rights OAU Doc OAU/ LEG/EXP/AFCHPR/PROT (III) arts $1 \&$ 2. For a discussion of the African Court on Human and Peoples' Rights and the African Commission, see E Badawi 'Draft Protocol to the African Charter on Human and Peoples' Rights on the Establishment of the African Court on Human and Peoples' Rights: Introductory note' (1997) 9 African Journal of International and Comparative Law 953.

120 Art 27(1) African Court Protocol (n 119 above). 
irreparable harm to persons, the Court shall adopt such provisional measures as it deems necessary. ${ }^{121}$

It is an indication that the orders the African Court makes are not limited to financial reparation. ${ }^{122}$ Rather, the Protocol mandates the Court to make 'appropriate orders', a requirement which is broad enough to encompass a declaration of inadmissibility of evidence obtained through human rights violations. ${ }^{123}$ Financial compensation is mentioned only as an example of orders that may be made; it is not to the exclusion of other appropriate orders as the Court may deem fit.

The Robben Island Guidelines specify the context of the evidence that will be dealt with, namely, evidence obtained through torture, cruel, inhuman and degrading treatment or punishment. The normative standard of the need to deal with torture limits the applicability of the guidelines beyond the violation of the right against torture. In the second place, this limitation affects the African Commission's role in the development of a normative framework to deal with evidence obtained through human rights violations, other than torture. Without prejudice to the foregoing, the Robben Island Guidelines recognise and concretise the right to human dignity of everyone, and that the state cannot violate the right for purposes of self-preservation. ${ }^{124}$ The Robben Island Guidelines are effective in ensuring that evidence obtained through torture or cruel, inhuman and degrading treatment is not admissible. This effectiveness does not extend to instances of evidence obtained through other human rights violations. To this extent the normative framework did not serve its purpose in as far as it did not deal with evidence obtained through all human rights violations.

\subsection{The Fair Trial Principles}

The fourth major development was the passing of a resolution to establish a working group to prepare a draft of general principles and guidelines on the right to a fair trial and legal assistance. ${ }^{125}$ The working groups involved in the drafting of these principles included

121 Art 27(2) African Court Protocol.

122 This formed the main type of remedy in the Tunis Resolution and the Dakar Declaration.

123 For a discussion on appropriate orders, see G Naldi 'Observations on the Rules of the African Court on Human and Peoples' Rights' (2014) 14 African Human Rights Law Journal 366381 . For reparations as a remedy, see G Naldi 'Reparations in the practice of the African Commission on Human and Peoples' Rights' (2001) 14 Leiden Journal of International Law 681; Mtikila $v$ Tanganyika Law Society and The Legal and Human Rights Law Centre and Reverend Christopher Mtikila v Tanzania App 009 \& 011/2011 para 126(4) 14 June 2013.

124 Moravcsik ( $n 44$ above) 518, on the state taking decisions for the welfare of its citizens.

125 Resolution on the Right to a Fair Trial and Legal Assistance in Africa, Res AHG/ 222(XXXVI); para 3 Robben Island Guidelines (n 12 above). 
academics, advocates, NGOs and other domestic players. ${ }^{126}$ This process led to the adoption of the Fair Trial Principles. ${ }^{127}$ There are four normative concepts in the Principles, which form the standard that guide the African Commission's mode of dealing with evidence obtained through human rights violations. ${ }^{128}$ This standard is dealt with in respect of four aspects: the right to an effective remedy; ${ }^{129}$ the role of prosecutors; ${ }^{130}$ the prohibition of the collection of evidence through a violation of a detained suspect's rights; ${ }^{131}$ and the rule on how to deal with evidence obtained through force or coercion. $^{132}$

First, with regard to an effective remedy, the Principles state: ${ }^{133}$

Everyone has the right to an effective remedy by competent national tribunals for acts violating the rights granted by the constitution, by law or by the Charter, notwithstanding that the acts were committed by persons in an official capacity.

Further: 134

Every state has an obligation to ensure that ... any person whose rights have been violated, including by persons acting in an official capacity, has an effective remedy by a competent judicial body.

The cumulative effect of this Principle is to widen the standard of an effective remedy by extending it from actual or pecuniary remedies to evidential remedies, such as the exclusion of evidence. This exclusion includes a violation that leads to any kind of harm other than physical harm, such as the violation of an accused's right to the presumption of innocence until proven guilty. ${ }^{135}$ This normative development requires the African Commission to call on state parties to provide an effective remedy, such as the exclusion of evidence obtained through human rights violations, by a competent judicial body. ${ }^{136}$

Second, prosecutors have a key role to play in instances where they have evidence that has been obtained through human right violations. The Principles state: ${ }^{137}$

When prosecutors come into possession of evidence against suspects that they know or believe on reasonable grounds was obtained through recourse to unlawful methods, which constitute a grave violation of the

126 Moravcsik (n 44 above) 517, with regard to the liberal theory's primacy on domestic actors as key players.

127 Fair Trial Principles (n 13 above). Baderin (n 13 above) 118.

128 Fair Trial Principles (n 13 above) Preamble.

129 Principle (C)(a) Fair Trial Principles.

130 Principle F Fair Trial Principles.

131 Principles $M(7)(d)-(f)$ Fair Trial Principles.

132 Principle $\mathrm{N}(6)(\mathrm{d})(1)$ Fair Trial Principles.

133 Principle C(a) Fair Trial Principles.

134 Principle C(c)(1) Fair Trial Principles.

135 Jean-Marie Atangana Mebara v Cameroon Communication 416/12 paras 81-83.

136 Principle C(c)(1) Fair Trial Principles (n 13 above).

137 Principle $F(\mathrm{I})$ Fair Trial Principles. 
suspect's human rights, especially involving torture or cruel, inhuman or degrading treatment or punishment, or other abuses of human rights, they shall refuse to use such evidence against anyone other than those who used such methods, or inform the judicial body accordingly, and shall take all necessary steps to ensure that those responsible for using such methods are brought to justice.

This Principle requires prosecutors to refrain from procuring the admission of evidence which has been obtained through a violation of a suspect's rights unless it is being admitted to be used against perpetrators of the human rights violations. A prosecutor exercises a discretion to establish whether the evidence was obtained through a disregard of rights. Once he forms the opinion that the evidence was obtained through a violation of human rights, then, first, he should not admit that evidence against the suspect; and, second, he should have that evidence admitted against the perpetrator(s) of the human rights violation. 138 This Principle creates a standard which recognises the need to deal with evidence obtained through human rights violations and in other improper ways. ${ }^{139}$ Furthermore, it places a significant role on prosecutors to ensure that impugned evidence is not tendered for admission. These normative developments require the state to desist from using its machinery to coerce people in its jurisdiction, without being accountable to the African Commission. ${ }^{140}$

Third, the Fair Trial Principles protect suspects in the course of the collection of evidence by the investigating arms of government. The relevant provision states that '[s]states shall ensure that all persons under any form of detention or imprisonment are treated in a humane manner and with respect for the inherent dignity of the human person'.141 This principle introduces distinct features that are instructive on evidence obtained through human rights violations. A person whose rights are infringed is still imbued with dignity. In addition, it is indicative that the collection of evidence should use the dignity of an individual as the yardstick. Furthermore, where the right to human dignity is violated, then the evidence that is being obtained may be questioned. ${ }^{142}$

Fourth, with regard to undue influence, the Fair Trial Principles deal with evidence obtained through any other form of coercion or undue influence. With regard to coercion, it provides: ${ }^{143}$

Any confession or other evidence obtained by any form of coercion or force may not be admitted as evidence or considered as probative of any fact at trial or in sentencing. Any confession obtained during incommunicado detention shall be considered to have been obtained by coercion.

138 Mujuzi (n 70 above) 287.

139 Principles $M(7)(d) \& F(I)$ Fair Trial Principles (n 13 above).

140 See the discussion on the liberal theory above.

141 Principle $M(7)(a)$ Fair Trial Principles (n 13 above). See $M(7)(a)-(f)$.

142 Nanima (n 93 above).

143 Principle $N(6)(d)(1)$ Fair Trial Principles (n 13 above). 
It is worth noting that this provision extends the standard from evidence obtained through human rights violations to improperlyobtained evidence, although from the wording of the provision its application is limited to evidence obtained through coercion or force. Principle $M(7)$ provides two instances where the application of the fourth concept may be extended. The first instance is the prohibition of taking undue advantage of a detained or imprisoned person by compelling him or her to confess, for the purposes of incriminating himself or herself or incriminating others. ${ }^{144}$ The second instance where the application of the fourth concept is extended is where a detained person is subjected to threats or methods of interrogation which impair his or her capacity for judgment. ${ }^{145}$ These methods relate to coercion, but the departure point is their ability to affect the fairness of a trial without having the blemish of human rights violations.

The interpretation of the four concepts forms the interrelated and interdependent normative framework on evidence obtained through human rights violations and improperly obtained evidence. The developments between 1995 and 1999 related generally to the right to a fair trial, but were not specific to evidence obtained through human rights violations. It was the normative developments, such as the adoption of the Robben Island Guidelines (2002) and the Principles (2003), which deal with the concept of evidence obtained through human rights violations as an integral part of the right to a fair trial. This development amounts to a change in the normative developments that would be instrumental in subsequent jurisprudential developments. A difference between the Dakar Declaration and the Principles is that, although the former was rather elaborate on the right to a fair trial, it missed the mark on evidence obtained through human rights violations. The Principles to a large extent deal with evidence obtained through human rights violations and improperly-obtained evidence.

The Fair Trial Principles reflect two principles that are key to the application of liberal theory. First, they protect vulnerable members of society when their liberty has been curtailed by the state. Second, they require that state actors, as in the case of domestic players, should protect vulnerable members of society. This need is evident in the requirement that prosecutors do not procure the admission of evidence obtained through human rights violations unless the evidence is to be used in evidence against the perpetrators of the human rights violations. The Principles effectively dealt with evidence obtained through all human rights violations, including evidence illegally obtained. This was a point of departure which demonstrates a move from slow effectiveness to a more effective framework on evidence obtained through human rights violations. As such, the

144 Principle $M(7)(d)$ Fair Trial Principles.

145 Principle $M(7)(e)$ Fair Trial Principles. 
Principles deal with the general standards that illuminate developments from the Tunis Resolution and the Dakar Declaration. In addition, the Principles reconcile the limited application of the Robben Island Guidelines to a more nuanced approach that embraces evidence obtained through human rights violations.

\section{Conclusion}

The current normative structure was developed on the standard of the right to a fair trial. This need arose because states were using impunity to rule their citizens, a position that many domestic players opposed. As such, the general development of the right to a fair trial is evident in the failure by the Tunis Resolution and the Dakar Declaration to deal with the admission of evidence obtained through human rights violations. The use of civil society was geared towards other aspects of the right to a fair trial, other than evidence obtained through human rights violations. The normative fortunes of the African Commission changed with the development of the Robben Island Guidelines, which deal with this impugned evidence but limited it to evidence obtained through torture. The Fair Trial Principles that were adopted a year later deal with evidence obtained through human rights violations and improperly-obtained evidence. Despite the change in the in-depth content, the Principles were introduced at a time when the normative framework had done little to alleviate the problem of dealing with evidence obtained through human rights violations.

It follows, if the African Commission employs liberal theory grounded in the various articles of the African Charter, it needs to carry out mass sensitisation and dissemination of information on the rights under the Charter. This position should be a precursor to the subsequent use of the views of domestic players. When domestic players are informed, they will offer informed views to guide the foreign policy of the respective states. The obligation to disseminate information should be placed on states to create programmes and legislation to support this cause.

There should be a study on the trends of the jurisprudence of the African Commission on evidence obtained through human rights violations to ascertain whether this normative framework has aided or limited its development. This demand is coupled with the fact that since its inception, the Commission has decided on 229 communications. ${ }^{146}$ Eighty-nine of these communications have been decided on their merits, representing 38 per cent of the total number of communications. ${ }^{147}$ Approximately 90 communications have been regarded as inadmissible, representing 39 per cent of the total

146 IHRDA African Human Rights Case Law Analyser; search documents http:// caselaw.ihrda.org/doc/search/? $\mathrm{m}=83$ (accessed 6 November 2016).

147 As above. 
number of communications. ${ }^{148}$ Subject to conceptual and empirical research, the normative concepts that inform evidence obtained through human rights violations are instructive in improving the normative and subsequent jurisprudential developments.

It is significant to visit the experiences of domestic, regional and international human rights systems to draw insights as to how their normative frameworks are developed. This study will guide future engagements on the creation of frameworks on aspects that fall within the mandate of the African Commission. In addition, it is a well-acknowledged principle that domestic laws may be used to contribute to the normative frameworks of a regional human rights system. ${ }^{149}$ It is argued that domestic courts may guide the Commission's creation of a normative framework that produces clarity on the issues that need to be addressed at the drafting stages.

148 As above.

149 S V M 2008 (3) SA 232 (CC) where the decision of the South African Supreme Court of Appeal was instructive in the content of General Comment 1 of 2014 regarding the caregivers and the children. 